\title{
Analisis Hubungan Sanitasi Lingkungan Terhadap Keluhan Penyakit Kulit
}

\author{
Zahtamal", Tuti Restuastuti, Ridha Restila, Yuni Eka Anggraini, Yusdiana \\ Fakultas Kedokteran, Universitas Riau, J1 Diponegoro No 1 Pekanbaru, Riau 28133, Indonesia \\ *Corresponding author: zahtamal@lecturer.unri.ac.id \\ Info Artikel:Diterima 4 Maret 2021 ; Direvisi 24 Oktober 2021 ; Disetujui 21 November 2021 \\ Tersedia online : 31 Januari 2022 ; Diterbitkan secara teratur : Februari 2022
}

Cara sitasi (Vancouver): Zahtamal Z, Restila R, Restuastuti T, Anggraini YE, Yusdiana Y. Analisis Hubungan Sanitasi Lingkungan Terhadap Keluhan Penyakit Kulit. Jurnal Kesehatan Lingkungan Indonesia [Online]. 2022 Feb;21(1):9-17. https://doi.org/10.14710/jkli.21.1.9-17.

\begin{abstract}
ABSTRAK
Latar belakang: Masalah sanitasi lingkungan antara lain ketersediaan air bersih, kondisi fisik rumah, keberadaan vektor dan binatang pembawa penyakit masih menjadi pemicu tingginya penyakit kulit di masyarakat. Tujuan penelitian ini adalah mengetahui hubungan sanitasi lingkungan terhadap keluhan penyakit kulit di masyarakat.

Metode: Jenis penelitian ini adalah analitik dengan desain cross sectional. Variabel dependen adalah keluhan penyakit kulit, sedangkan variabel independen antara lain sumber air bersih dan air minum, jamban, saluran pembuangan air limbah (SPAL), kondisi rumah (tata ruang, sekat pada dapur, dinding rumah, ventilasi ruang keluarga dan kamar tidur, lubang udara pada dapur, dan kepadatan hunian kamar tidur), tanda keberadaan binatang dan vektor pembawa penyakit (tikus, kecoa, nyamuk, serangga). Pengumpulan data variabel independen dilakukan dengan wawancara dan observasi, sedangkan variabel dependen dilakukan melalui variabel dependen (keluhan penyakit kulit) dilakukan melalui pemeriksaan klinis dan hasil diagnosis oleh dokter spesialis kulit dan kelamin. Populasi penelitian adalah seluruh masyarakat di desa Ranah. Jumlah sampel menggunakan rumus estimasi proporsi didapatkan jumlah sampel 245 orang. Teknik pengambilan sampel menggunakan purposive sampling. Data dianalisis dengan chi-square dan regresi logistik berganda.

Hasil: Hasil penelitian ini menunjukkan 36,73\% (95\% CI: 30,69\% - 42,76\%) responden mengalami keluhan penyakit kulit. Analisis bivariat didapatkan hanya ventilasi tidak memenuhi syarat yang berhubungan signifikan terhadap masalah kesehatan kulit ( $p$ value 0,001). Sementara sumber air bersih dan air minum, jamban,SPAL), jenis lantai rumah, kondisi rumah lainnya dan keberadaan binatang dan vektor pembawa penyakit tidak berhubungan signifikan terhadap keluhan penyakit kulit ( $p$ value $>0,05)$. Analisis multivariat diperoleh hasil faktor risiko yang paling berhubungan adalah ventilasi ruang keluarga ( $p$ value 0,0001, adjusted OR 6,34), kemudian SPAL (pvalue 0,02 adjusted OR 2,51), dan keberadaan vektor pembawa penyakit (serangga) ( $p$ value 0,007 adjusted OR 2,44)
\end{abstract}

Simpulan: Penelitian ini membuktikan faktor lingkungan yang berpengaruh terhahap keluhan penyakit kulit adalah ventilasi, sumber air minum, SPAL, dan keberadaan serangga.

Kata kunci: air bersih; jamban rumah tangga; keluhan penyakit kulit; kondisi rumah

\section{ABSTRACT}

Title: Relationship of Environmental sanitation with Complaints of Skin Disease

Background: Environmental sanitation problems include the availability of clean water, the physical condition of the house, the presence of vectors and disease-carrying animals that still trigger high levels of skin disease in 
the community. The purpose of this study was to determine the relationship between environmental sanitation and complaints of skin diseases in the community.

Method: This study used a quantitative approach with a sectional corss study design. Data collection for the independent variables was carried out by interview and observation, while the dependent variable was carried out through clinical interviews. The environmental aspects studied were sources of clean and drinking water, latrines, sewerage (SPAL), house conditions (layout, kitchen partition, walls of permanent houses, house and bedroom ventilation, air holes in the kitchen, and room density), and signs of the presence of animals and disease-carrying vectors (rats, cockroaches, mosquitoes, insects, and flies). The number of samples was 245 people taken by purposive sampling. Data were analyzed by chi-square and multiple logistic regression.

Result: The results of this study showed that 36.73\% (95\% CI: 30.69\% - 42.76\%) of respondents had complaints of skin disease. Bivariate analysis found that only ventilation had a significant effect on skin health problems (Pvalue 0.001). Meanwhile, clean and drinking water sources, latrines, sewerage), types of house floors, other house conditions and the presence of animals and disease-carrying vectors did not have a significant relationship with skin problems ( $p$ value $>0.05$ ). Multivatiate analysis showed that the most influential risk factors were house ventilation ( $p$ value 0.0001, adjusted OR 6.34), then SPAL ( $p$ value 0.02 adjusted OR 2.51), and the presence of disease-carrying vectors (insects) (p. value 0.007 adjusted OR 2.44)

Conclusion: Environmental factors that affect symptoms of skin disease in the community are air ventilation, SPAL, and the presence of insects. The sanitation factor was not significantly related.

Keywords: clean water; household latrine; house condition; skin diseases

\section{PENDAHULUAN}

Masalah kesehatan kulit atau penyakit kulit adalah salah satu penyakit atau kelainan yang memengaruhi kulit manusia. Seperti jaringan lain, kulit dipengaruhi oleh semua jenis perubahan patologis, termasuk proses herediter, inflamasi, neoplastik baik yang jinak maupun ganas, endokrin, hormonal, traumatis, dan degeneratif. Emosi juga memengaruhi kesehatan kulit. Reaksi kulit terhadap penyakit dan kelainan ini berbeda dari jaringan lain dalam banyak hal. Misalnya, peradangan kulit yang luas dapat memengaruhi metabolisme di dalam organ dan sistem tubuh lain, menyebabkan anemia, gangguan sirkulasi, gangguan suhu tubuh, dan gangguan keseimbangan air dan elektrolit dalam darah. $^{(1)}$

Penyebab kelainan atau penyakit kulit sangat beragam, antara lain: 1) Penyakit kulit karena peradangan (dermatitis). Kondisi ini terjadi ketika kulit bersentuhan dengan bahan yang bersifat iritatif atau dengan alergen (zat atau benda yang menyebabkan reaksi alergi), 2) Penyakit kulit karena kelainan autoimun, yang terjadi ketika sistem kekebalan tubuh menyerang dan menghancurkan jaringan tubuh yang sehat, dan 3) Penyakit kulit karena infeksi, antara lain dari bakteri, virus, jamur, maupun parasit. Penyakit kulit akibat infeksi ini umumnya menular. ${ }^{(2-4)}$

Masalah kesehatan kulit ini masih menjadi persoalan kesehatan yang sering ditemukan pada masyarakat di seluruh belahan dunia, termasuk Indonesia. Beberapa hasil penelitian dapat memberikan gambaran penyakit kulit yang tersering dialami masyarakat.. Penelitian dengan menggunakan catatan medik pasien Poliklinik Kulit dan Kelamin RSUP Dr. Kariadi Semarang periode 1 Januari 2008 31 Desember 2010 didapatkan 3.154 orang $(33,52 \%)$ penderita penyakit kulit akibat infeksi dari 9.409 penderita penyakit kulit maupun kelamin. Dari keseluruhan penyakit kulit akibat infeksi, terdapat infeksi virus sejumlah 897 kasus (9,53\%), infeksi bakteri sejumlah 584 kasus $(6,20 \%)$ dan infeksi jamur superfisial sejumlah 1.673 kasus (17,78\%). Salah satu jenis penyakit infeksi adalah scabies. Prevalensi scabies di seluruh dunia diperkirakan mencapai 200 juta kasus pertahun atau berada pada rentang 0,2 $71 \%{ }^{(5)}$ Di Indonesia diperkirakan angka kejadian mecapai 4,6 sampai $12,95 \% .^{(6)}$

Masalah kesehatan kulit di masyarakat dapat terjadi akibat berbagai faktor, antara lain faktor sanitasi lingkungan dan perilaku. Mengacu pada teori simpul, ${ }^{(7)}$ maka masalah kesehatan kulit dapat dijelaskan sebagai interaksi simpul 2 yaitu komponen lingkungan yang menjadi media transmisi dengan simpul 3 yaitu karakteristik kependudukan yaitu perilaku manusia. Interaksi ini akan menimbulkan outcome sakit atau tidak sakit pada suatu individu (simpul 4). Sanitasi sendiri, menurut Kamus Besar Bahasa Indonesia (KBBI) adalah usaha untuk membina dan menciptakan suatu keadaan yang baik di bidang kesehatan, terutama kesehatan masyarakat. Sanitasi lingkungan adalah cara menyehatkan lingkungan hidup manusia terutama lingkungan fisik, yaitu tanah, air, dan udara. ${ }^{(8)}$ Menurut WHO, sistem sanitasi dirancang dan dikelola untuk melindungi kesehatan manusia dari bahaya yang disebabkan oleh eksreta manusia yang dapat merugikan kesehatan. Sistem sanitasi lingkungan melingkupi kondisi jamban, saluran pembuangan, pembuangan akhir, kontaminasi oleh binatang, vektor, kontaminasi air permukaan, kontaminasi air tanah, dan kontaminasi air. ${ }^{(9)}$ Kondisi sanitasi lingkungan yang tidak sehat dapat menjadi pemicu timbulnya masalah kesehatan kulit. Komponen lingkungan tersebut antara lain; sumber air bersih dan air minum, jamban rumah tangga, saluran pembuangan air limbah (SPAL), ${ }^{(10-12)}$ 
kondisi rumah (jenis lantai rumah, ventilasi udara, dll) dan keberadaan binatang dan vektor pembawa penyakit di rumah ${ }^{(13)}$ merupakan faktor yang terbukti menyebabkan timbulnya masalah kesehatan kulit.

Desa Ranah merupakan salah satu desa di Kabupaten Kampar yang terletak di tepi aliran sungai Kampar. Secara geografis masalah kesehatan kulit merupakan salah satu masalah kesehatan yang sering dijumpai pada masyarakat Indonesia khususnya pada daerah aliran sungai. ${ }^{(14)}$ Penyebab timbulnya penyakit beragam, dapat berupa infeksi jamur, virus, parasit, dan lain sebagainya. Sebagian besar penyakit kulit dapat menular dari satu individu ke individu lain. Hasil wawancara dengan kepala Puskesmas Kampar dan Pustu di desa Ranah menyebutkan masih banyaknya masyarakat yang mengalami masalah kesehatan kulit. Hal yang sama juga dijelaskan oleh perangkat Desa Ranah (Sekdes, kepala dusun, dan kader) bahwa masyarakat banyak yang mengeluhkan penyakit kulit terutama pada anak-anak usia sekolah dan Balita, meskipun aktivitas masyarakat di sungai seperti MCK sudah jarang dilakukan. Sulitnya memperoleh data untuk jenis dan jumlah penyakit kulit dapat memengaruhi keberhasilan upaya pencegahan dan penanggulangan penyakit kulit di masyarakat. Untuk itu, upaya pencegahan dan penatalaksanaan yang tepat dapat mencegah meluasnya suatu masalah kesehatan kulit di masyarakat.

Sampai saat ini, masalah kesehatan kulit kurang menjadi perhatian. Hal ini dikarenakan kebanyakan masyarakat beranggapan penyakit kulit tidak berbahaya atau tidak menyebabkan kematian. Padahal di sisi lain, penyakit kulit ini dapat berdampak buruk ke berbagai aspek, misalnya produktivitas masyarakat yang rendah, kemiskinan, penurunan prestasi belajar (terutama pada anak usia sekolah), dan lain-lain. ${ }^{(15,16)}$ Eratnya kaitan antara sanitasi lingkungan dan kejadian penyakit kulit, namun masih minimnya penelitian tentang keterkaitan ke dua hal ini, maka perlu dilakukan penelitian lebih lanjut. Selain itu, tentunya diharapkan dari hasil penelitian ini dimanfaatkan untuk perencanaan program kesehatan di tingkat pelayanan kesehatan dalam mengatasi persoalan penyakit kulit berbasis riset, khususnya terkait dengan pengelolaan lingkungannya. Sulitnya memperoleh data untuk jenis dan jumlah penyakit kulit juga dapat memengaruhi keberhasilan upaya pencegahan dan penanggulangan penyakit kulit di masyarakat. Tujuan penelitian ini adalah mengetahui hubungan sumber air bersih dan air minum, jamban rumah tangga, saluran pembuangan air limbah (SPAL), kondisi kesehatan rumah (Tata ruang rumah bersekat, sekat/dinding pada dapur, dinding rumah permanen, ventilasi ruang keluarga dan kamar tidur, lubang udara pada dapur, dan kepadatan kamar tidur, jenis lantai rumah, ventilasi udara) dan keberadaan binatang dan vektor pembawa penyakit di rumah terhadap keluhan penyakit kulit di masyarakat.

\section{MATERI DAN METODE}

Jenis penelitian ini menggunakan analitik observasional dengan desain studi cross sectional. Populasi penelitian adalah seluruh masyarakat yang menetap di Desa Ranah berjumlah 3055 orang. Teknik pemilihan sampel adalah purposive sampling. Hasil hitung sampel menggunakan rumus hitung sampel minimal untuk estimasi proporsi. Hasil hitung sampel minimalnya adalah 217 sampel, namun pada penelitian ini jumlah sampel ditambahkan sebesar 10\% sehingga jumlah sampel menjadi 245 sampel.

Pengumpulan data untuk variabel-variabel independen (faktor sanitasi lingkungan) dilakukan dengan wawancara dan observasi. Aspek lingkungan yang diteliti adalah sumber air bersih dan air minum, jenis jamban di rumah, saluran pembuangan air limbah (SPAL), kondisi kesehatan rumah (kondisi rumah bersekat antar ruangan, kondisi dinding rumah permanen, luas ventilasi ruang keluarga dan kamar tidur, lubang udara pada dapur, dan kepadatan kamar tidur) dan keberadaan binatang dan vektor pembawa penyakit di rumah. Selanjutnya, data variabel dependen (keluhan penyakit kulit) dilakukan melalui pemeriksaan klinis dan hasil diagnosis oleh dokter spesialis kulit dan kelamin. Lokasi penelitian adalah Desa Ranah Kecamatan Kampar, Kabupaten Kampar. Data dianalisis dengan uji chisquare dan regresi logistik ganda. Hasil analisis bivariat dianalisis lanjut menggunakan regresi logistik ganda, untuk melihat variabel mana yang signifikan terhadap kejadian keluhan penyakit kulit di masyarakat. Langkah awal adalah dengan seleksi bivariat, seluruh variabel independen yang miliki nilai pvalue $<0,25$ akan dianalisis secara bersamaan. Variabel-variabel yang tidak signifikan ( $p$ value $<0,05$ ) akan dikeluarkan satu persatu dari model (metode enter). Apabila variabel yang dikeluarkan mengakibatkan perubahan OR $>10 \%$ pada variabel lain, maka dimasukan kembali kedalam model. Kemaknaan statistik untuk melihat hubungan antar variabel pada penelitian ini pada tingkat signifikansi/ $p$ value 0,05 . Penelitian ini telah lulus kaji etik dari Unit Etik Penelitian Kedokteran dan Kesehatan Fakultas Kedokteran Universitas Riau No B/067/UN19.5.1.1.8/UEPKK/2020.

\section{HASIL DAN PEMBAHASAN}

Desa Ranah merupakan salah satu desa yang berada di wilayah kerja Puskesmas Kampar, Kecamatan Kampar Kabupaten Kampar, Provinsi Riau. Secara geografis, desa ini berada di daerah aliran sungai Kampar Kanan. Masyarakat di dasa ini Sebagian besar dengan kategori status ekonomi menengah ke bawah, serta sanitasi pemukiman masyarakatnya yang relatif kurang memadai. Secara administratif, Desa Ranah terdiri dari 4 Dusun. Setiap dusun memiliki 2 RW dan setiap RW terdapat 2 RT, sehingga secara keseluruhan desa ini memiliki 4 dusun, 8 RW dan 16 RT. Luas wilayah desa terdiri dari pemukiman 42,5ha, ladang tegalan 41,5ha, 
perkebunan 117,6 ha, perkantoran 0,25 ha, sekolah 0,79 ha, jalan 4 ha, lapangan sepak bola 1,21 ha.

Hasil penelitian ini menunjukkan, dari 245 responden yang diwawancarai, diperoleh hasil 90 orang $(36,73 \%$; 95\% CI 30,69\% - 42,76\%) mengalami keluhan penyakit kulit selama 1 bulan terakhir.
Berdasarkan karakteristik jenis kelamin, kelompok responden laki-laki mengalami keluhan penyakit kulit yang lebih banyak dibandingkan perempuan. Kelompok umur yang paling banyak mengalami keluhan penyakit kulit adalah Balita. Hal ini dapat dilihat pada tabel berikut:

Tabel 1. Karakteristik Responden

\begin{tabular}{|c|c|c|c|c|}
\hline \multirow[t]{2}{*}{ Karakteristik Responden } & \multicolumn{4}{|c|}{ Keluhan Penyakit Kulit } \\
\hline & $\mathbf{Y a}$ & $\%$ & Tidak & $\%$ \\
\hline \multicolumn{5}{|l|}{ Jenis Kelamin } \\
\hline Laki - Laki & 44 & 41,1 & 63 & 58,9 \\
\hline Perempuan & 46 & 33,3 & 92 & 66,7 \\
\hline \multicolumn{5}{|l|}{ Usia } \\
\hline $0-5$ tahun & 11 & 52,4 & 10 & 47,6 \\
\hline $6-11$ tahun & 8 & 40 & 12 & 60 \\
\hline $12-25$ tahun & 25 & 35,2 & 46 & 64,8 \\
\hline $26-45$ tahun & 20 & 30,3 & 46 & 69,7 \\
\hline $46-65$ tahun & 23 & 38,3 & 37 & 61,7 \\
\hline$>65$ tahun & 3 & 42,9 & 4 & 57,1 \\
\hline Jumlah & 90 & 36,7 & 155 & 63,3 \\
\hline
\end{tabular}

Selanjutnya, penelitian ini dilakukan untuk melihat bagaimana faktor risiko lingkungan terhadap keluhan penyakit kulit yang dialami oleh masyarakat. Adapun faktor risiko yang diteliti yakni hubungan sumber air bersih dan air minum, jamban rumah tangga, saluran pembuangan air limbah (SPAL), jenis lantai rumah, ventilasi udara dan keberadaan vektor pembawa penyakit di rumah terhadap keluhan penyakit kulit masyarakat.

\section{Hubungan Air Bersih dan Air Minum Dengan Keluhan Penyakit Kulit}

Berdasarkan hasil penelitian ini dapat dilihat bahwa sumber air baik air minum maupun air bersih tidak berhubungan secara signifikan terhadap kejadian keluhan penyakit kulit di masyarakat (Tabel 2). Namun demikian, perlu dilakukan analisis lanjutan (dalam penelitian ini menggunakan regresi logistik ganda) untuk mengontrol variabel lain yang dapat memengaruhi hasil analisis statistik.

Tabel 2. Hubungan Jenis Sumber Air Bersih dan Air Minum dengan Keluhan Penyakit Kulit

\begin{tabular}{|c|c|c|c|c|c|c|}
\hline \multirow[t]{2}{*}{ No } & \multirow[t]{2}{*}{ Aspek air bersih dan air minum } & \multicolumn{4}{|c|}{ Keluhan penyakit Kulit } & \multirow[t]{2}{*}{ p value } \\
\hline & & $\begin{array}{c}\text { Ya } \\
(\mathbf{n}=90)\end{array}$ & $\%$ & $\begin{array}{c}\text { Tidak } \\
(n=155)\end{array}$ & $\%$ & \\
\hline \multirow[t]{3}{*}{1} & Sumber Air Bersih & & & & & \\
\hline & Sungai/Danau, Air Hujan, Lainnya & 7 & 23,3 & 23 & 76,7 & 0,155 \\
\hline & Sumur Cincin, sumur bor & 83 & 38,6 & 132 & 61,4 & \\
\hline \multirow[t]{3}{*}{2} & Sumber Air Minum & & & & & \\
\hline & Bukan air isi ulang & 24 & 30,4 & 55 & 69,6 & 0,2 \\
\hline & Air isi ulang & 66 & 39,8 & 100 & 60,2 & \\
\hline
\end{tabular}

Hasil analisis regresi logistik ganda pada penelitian ini (tabel 7 dan tabel 8) diperoleh faktor risiko yang menyebabkan timbulnya masalah kesehatan kulit adalah air minum, dan sumber air bersih sebagai variabel confounding. Selanjutnya, pada tahapan analisis dengan seluruh variabel dikontrol, ditemukan adanya hubungan antara air minum dengan masalah kesehatan kulit. Jenis sumber air minum yang dikonsumsi masyarakat Desa Ranah sebagian besar adalah air minum isi ulang. Analisis yang dilakukan adalah pengelompokan air minum berdasarkan air isi ulang dan non-isi ulang (air sungai, air sumur cincin dan sumur bor, sumber mata air). Pada penelitian ini sumber air minum non-isi ulang merupakan faktor protektif terhadap masalah kesehatan kulit. Hal ini dilihat dari hasil analisis dengan nilai $\mathrm{OR}<1$. Analisis regresi logistik diperoleh hasil Adjusted OR 0,42; 95\%CI 0,21 - 0,82 yang artinya odds kejadian penyakit kulit pada masyarakat yang memiliki sumber air minum bukan air isi ulang lebih kecil 0,42 kali dibandingkan sumber air minum isi ulang setelah di kontrol variabel lainnya (sumber air bersih, SPAL, ventilasi rumah dan keberadaan serangga). Hasil ini dapat dimungkinkan bahwa adanya perbedaan pengolahan air minum dari sumbernya misalnya pada kelompok responden yang menggunakan sumber air minum non-isi ulang memasak air terlebih dahulu, sementara pada kelompok air minum isi ulang tidak diolah sebelum dikonsumsi. Perlu dilakukan penelusuran lebih lanjut tentang pengolahan air minum sebelum dikonsumsi (dimasak/tidak), analisis kualitas air minum (terutama biologi dan kimia), serta cara dan lama penyimpanan air minum sebelum dikonsumsi.

Air merupakan kebutuhan vital untuk setiap makhluk hidup. Untuk kebutuhan dasar manusia, air 
dibedakan menjadi air bersih dan air minum. Berdasarkan PMK No 32 Tahun 2017, air untuk keperlukan higiene sanitasi adalah air dengan kualitas tertentu yang digunakan untuk keperluan sehari - hari seperti mandi, dan sikat gigi, serta untuk keperluan cuci bahan pangan, peralatan makan, dan pakaian. Seperti halnya air minum, air untuk keperluan higiene sanitasi harus memenuhi standar baku mutu kesehatan lingkungan yang meliputi parameter fisik, biologi dan kimia. $^{(17)}$ Kualitas air yang tidak memenuhi baku mutu dapat menimbulkan masalah kesehatan, salah satunya penyakit kulit, dimana air yang tercemar dapat berkontak langsung dengan kulit.

Selain kontak langsung dengan sumber (zat kimia, infeksi jamur, bakteri dan virus), masalah kesehatan dipengaruhi oleh semua jenis perubahan patologis, termasuk proses herediter, inflamasi, neoplastik baik yang jinak maupun ganas, endokrin, hormonal, traumatis, dan degeneratif. Emosi juga memengaruhi kesehatan kulit. Reaksi kulit terhadap penyakit dan kelainan ini berbeda dari jaringan lain dalam banyak hal. ${ }^{(1)}$

Konsumsi air minum yang tercemar dapat menyebabkan berbagai masalah kesehatan termasuk penyakit kulit. Penelitian tentang pencemaran air minum di Bangladesh menyebutkan paparan arsenik kronis dari air minum dikaitkan dengan peningkatan insiden lesi kulit, bahkan pada tingkat paparan arsenik yang rendah $(<100 \mu \mathrm{g} / \mathrm{L})^{(18)}$. Asupan arsenik yang berlebihan dan dalam jangka panjang (seperti 5-10 tahun) pada air minum dan makanan dapat menyebabkan arsenikosis, nama umum yang umumnya digunakan untuk masalah kesehatan terkait termasuk gangguan kulit, kanker kulit, kanker internal (kandung kemih), ginjal, dan paru-paru, penyakit pada pembuluh darah di tungkai dan kaki, kemungkinan diabetes, peningkatan tekanan darah, dan gangguan reproduksi. $^{(19,20)}$

Penyebab tidak langsung kontaminasi air minum terhadap masalah kesehatan kulit dapat juga terjadi. Sebagian besar bakteri patogen yang terdapat dalam air akan menginfeksi saluran pencernaan dan dikeluarkan melalui kotoran manusia dan hewan lain yang terinfeksi (water borne infection). Seringnya tubuh mengalami infeksi melalui air dikonsumsi, membuat daya tahan tubuh juga akan berkurang. Kondisi ini semakin parah apabila terjadi pada kelompok rentan seperti pada anak balita dan lansia. Kondisi imun yang rendah tentunya menyebabkan rentannya seseorang menderita penyakit infeksi, termasuk penyakit kulit karena rendahnya kemampuan proteksi kulit sebagai mekanisme pertahanan tubuh.

\section{Hubungan Jamban dengan Keluhan Penyakit Kulit.}

Berdasarkan Tabel 3, diketahui bahwa berdasarkan analisis bivariat diperoleh hasil jamban rumah tangga tidak berhubugan dengan keluhan penyakit kulit ( $p$ value 0,75). Selain jenis jamban, pembuangan saluran jamban juga diperoleh hasil tidak signifikan terhadap keluhan penyakit kulit ( $p$ value $0,339)$. Hasil uji statistik kedua variabel ini kemudian tidak dilanjutkan ke analisis regresi logistik berganda karena memiliki nilai $p$ value $>0,25$ (Tabel 7).

Tabel 3. Hubungan Jenis Jamban Rumah Tangga dengan Keluhan Penyakit Kulit

\begin{tabular}{|c|c|c|c|c|c|c|}
\hline \multirow[t]{2}{*}{ No } & \multirow[t]{2}{*}{ Jamban Rumah Tangga } & \multicolumn{4}{|c|}{ Keluhan penyakit Kulit } & \multirow[t]{2}{*}{ p value } \\
\hline & & $\begin{array}{c}\text { Ya } \\
(n=90)\end{array}$ & $\%$ & $\begin{array}{c}\text { Tidak } \\
(n=155)\end{array}$ & $\%$ & \\
\hline \multirow[t]{3}{*}{1} & Jenis jamban yang digunakan & & & & & 0,75 \\
\hline & Bukan jamban leher angsa & 3 & 30 & 7 & 70 & \\
\hline & Jamban leher angsa & 87 & 37 & 148 & 63 & \\
\hline \multirow[t]{3}{*}{2} & Pembuangan saluran jamban & & & & & 0,339 \\
\hline & Bukan septic tank & 16 & 30,2 & 37 & 69,8 & \\
\hline & Septic tank & 74 & 38,5 & 118 & 61,6 & \\
\hline
\end{tabular}

Sebagaimana telah dipaparkan sebelumnya, sanitasi lingkungan melingkupi status kesehatan perumahan, SPAL, penyediaan air bersih, pembuangan kotoran dan lain sebagainya. Kondisi lingkungan yang tidak sehat seperti jamban yang tidak sehat, kurangya air bersih, dan ketersediaan SPAL merupakan faktor yang menyebabkan timbulnya masalah kesehatan kulit. ${ }^{(12,21)}$ Akan tetapi, dalam penelitian ini peneliti tidak mendapatkan hubungan yang signifikan jamban rumah tangga dan jenis pembuangan saluran jamban terhadap kejadian keluhan penyakit kulit di masyarakat. Hal ini disebabkan oleh karena, kondisi jamban yang tidak sehat, berpengaruh secara tidak langsung terhadap keluhan penyakit kulit, misalnya melalui pencemaran air yang dikonsumsi, dan keberadaan vektor serta binatang penyebab/pembawa penyakit. Kondisi jamban erat kaitannya dengan pencemaran lingkungan terutama sumber air. Syarat jamban yang sehat salah satunya adalah tidak mencemari sumber air untuk sanitasi dan air minum. Apabila buangan dari jamban telah mencemari sumber air, tentunya dapat memicu timbulnya beberapa penyakit kulit.

\section{Hubungan Pembuangan Air Limbah dengan Keluhan Penyakit Kulit}

Berdasarkan Tabel 4 diketahui bahwa jenis saluran pembuangan air limbah yang digunakan di rumah tangga dan jarak antara lubang resapan SPAL dengan sumber air tidak signifikan terhadap kejadian keluhan penyakit kulit di masyarakat. Meskipun kedua variabel tersebut tidak signifikan, jenis saluran 
pembuangan air limbah (SPAL) yang digunakan oleh mengontrol variabel lainnya (Tabel 7). responden dapat dianalisis lebih lanjut untuk Tabel 4. Hubungan Jenis dan Kondisi Pembuangan Air Limbah dengan Keluhan Penyakit Kulit

\begin{tabular}{|c|c|c|c|c|c|c|}
\hline \multirow[t]{2}{*}{ No } & \multirow[t]{2}{*}{ Pembuangan Air Limbah Rumah Tangga } & \multicolumn{4}{|c|}{ Keluhan penyakit Kulit } & \multirow[t]{2}{*}{ p value } \\
\hline & & $\begin{array}{c}\text { Ya } \\
(\mathbf{n}=90)\end{array}$ & $\%$ & $\begin{array}{c}\text { Tidak } \\
(\mathrm{n}=155)\end{array}$ & $\%$ & \\
\hline \multirow[t]{3}{*}{1} & $\begin{array}{l}\text { Jenis saluran pembuangan air limbah } \\
\text { (SPAL) yang digunakan di rumah }\end{array}$ & & & & & 0,199 \\
\hline & Saluran terbuka, dibuang sembarang & 74 & 39,2 & 115 & 60,8 & \\
\hline & Saluran tertutup, sumur resapan & 16 & 28,6 & 40 & 71,4 & \\
\hline \multirow[t]{3}{*}{2} & $\begin{array}{l}\text { Jarak antara lubang peresapan SPAL } \\
\text { dengan sumber air }<10 \mathrm{~m}\end{array}$ & & & & & 0,699 \\
\hline & $\mathrm{Ya}$ & 58 & 35,6 & 105 & 64,4 & \\
\hline & Tidak & 32 & 39,1 & 50 & 60,9 & \\
\hline
\end{tabular}

Faktor risiko yang juga berhubungan dengan penyakit kulit dalam penelitian ini adalah SPAL. SPAL merupakan salah satu pilar program pemerintah yaitu Sanitasi Total Berbasis Masyarakat (STBM). Air limbah rumah tangga dihasilkan dari aktivitas seperti mencuci, mandi, memasak makanan dan minuman, dan penggunaan toilet. Air limbah ini, apabila tidak dikelola dengan baik (penyaluran, pengumpulan dan pengolahan) akan mengakibatkan pencemaran air. Gangguan kesehatan akibat pencemaran air limbah ini bermacam-macam, salah satunya penyakit kulit. Hasil penelitian menunjukkan odds kejadian keluhan penyakit kulit lebih besar 2,51 kali pada kondisi SPAL terbuka dibandingkan dengan SPAL tertutup (Tabel 8). Hasil ini sejalan dengan penelitian lainnya, dimana air yang tercemar akibat pengelolaan SPAL yang tidak baik menyebabkan gangguan kesehatan kulit terutama pada usia rentan yaitu usia lanjut dan anak - anak. ${ }^{(10,11)}$

Air limbah rumah tangga yang tidak dikelola secara optimal/saniter berpotensi menimbulkan terjadinya pencemaran tanah dan berkembang biaknya vektor serta binatang pembawa penyakit seperti kecoa, tikus, lalat dan lain sebagainya. Pencemaran tanah berpotensi menyebabkan terjadinya pencemaran air baik untuk keperluan air bersih maupun air minum. Berdasarkan penjelasan teori/bukti empirik di atas, telah terbukti kualitas air memengaruhi penyakit kulit. Selanjutnya, keberadaan vektor dan binatang pembawa penyakit juga terbukti sebagai faktor risiko dan penyebab timbulnya penyakit kulit.

\section{Hubungan Kondisi Rumah dengan Keluhan Penyakit Kulit}

Berdasarkan Tabel 5 diketahui bahwa tidak semua aspek kondisi rumah berhubungan signifikan dengan keluhan penyakit kulit. Hanya variabel rumah yang memiliki ventilasi $<20 \%$ dari luas lantai berhubungan secara signifikan terhadap kejadian keluhan penyakit kulit di masyarakat.

Tabel 5 Hubungan Kondisi Rumah dengan Keluhan Penyakit Kulit

\begin{tabular}{|c|c|c|c|c|c|c|}
\hline \multirow[t]{2}{*}{ No } & \multirow[t]{2}{*}{ Kondisi Rumah yang Diamati } & \multicolumn{4}{|c|}{ Keluhan penyakit Kulit } & \multirow[t]{2}{*}{ p value } \\
\hline & & $\begin{array}{c}\text { Ya } \\
(\mathbf{n}=90)\end{array}$ & $\%$ & $\begin{array}{c}\text { Tidak } \\
(\mathrm{n}=155)\end{array}$ & $\%$ & \\
\hline \multirow[t]{3}{*}{1} & Tata ruang rumah tidak bersekat & & & & & 0,3 \\
\hline & $\mathrm{Ya}$ & 0 & 0 & 3 & 100 & \\
\hline & Tidak & 90 & 37,2 & 152 & 62,8 & \\
\hline \multirow[t]{3}{*}{2} & Tidak terdapat sekat pemisah dapur & & & & & 0,75 \\
\hline & Ya & 3 & 30 & 7 & 70 & \\
\hline & Tidak & 87 & 37,1 & 148 & 62,9 & \\
\hline \multirow[t]{3}{*}{3} & Dinding rumah permanen & 77 & 36,5 & 134 & 63,5 & \\
\hline & Semi permanen & 7 & 38,9 & 11 & 61,1 & 0,978 \\
\hline & Kayu/triplek & 6 & 37,5 & 10 & 62,5 & \\
\hline \multirow[t]{3}{*}{4} & Ventilasi $<20 \%$ dari luas lantai & & & & & 0,001 \\
\hline & $\mathrm{Ya}$ & 21 & 65,6 & 11 & 34,4 & \\
\hline & Tidak & 69 & 32,4 & 144 & 67,6 & \\
\hline \multirow[t]{3}{*}{5} & $\begin{array}{l}\text { Ventilasi kamar tidur }<20 \% \text { dari luas } \\
\text { lantai }\end{array}$ & & & & & 0,16 \\
\hline & Ya & 31 & 44,3 & 39 & 55,7 & \\
\hline & Tidak & 59 & 33,7 & 116 & 66,3 & \\
\hline \multirow[t]{3}{*}{6} & Tidak terdapat lubang udara di dapur & & & & & 0,845 \\
\hline & Ya & 18 & 34,6 & 34 & 65,4 & \\
\hline & Tidak & 72 & 37,5 & 121 & 62,5 & \\
\hline \multirow[t]{2}{*}{7} & $\begin{array}{llll}\begin{array}{l}\text { Kepadatan } \\
\text { mencukupi }\end{array} & \text { kamar } & \text { tidur } & \text { tidak } \\
\end{array}$ & & & & & 0,211 \\
\hline & Ya & 40 & 42,1 & 55 & 57,9 & \\
\hline
\end{tabular}


100

66,7

Kondisi rumah yang berkaitan dengan timbulnya penyakit kulit adalah bagaimana kualitas fisik dan kimia dari suatu rumah meliputi pencahayaan, suhu, kelembapan, dan keberadaan polutan di dalam rumah $\left(\mathrm{CO}, \mathrm{CO}_{2}\right.$, asbes, dan lain lain). Kondisi fisik dan kimia rumah yang jelek akan meningkatkan keberadaan dan kemampuan bertahan hidup mikroorganisme penyebab penyakit kulit di dalam rumah (virus, bakteri, parasit, jamur) serta memicu timbulnya reaksi alergi dan iritan.

Hasil penelitian ini menunjukkan ventilasi ruang keluarga merupakan variabel yang paling dominan menyebabkan keluhan penyakit. Ventilasi erat kaitannya dengan kualitas udara dan kesehatan. Timbulnya permasalahan kesehatan akibat kualitas udara yang buruk salah satunya disebabkan oleh kurangnya ventilasi udara dalam ruang atau bangunan. Ventilasi dapat membuat pergantian udara dalam ruangan, intensitas cahaya dan memengaruhi tingkat kelembapan ruangan. ${ }^{(22)}$ Pada penelitian ini, ventilasi udara berhubungan dengan keluhan penyakit kulit. Adjusted OR menunjukkan odds kejadian keluhan penyakit kulit lebih besar 6,34 kali pada rumah yang tidak memiliki ventilasi cukup dibandingkan rumah yang memiliki ventilasi yang cukup. Penelitian pada penghuni Lembaga Pemasyarakatan Kelas IIA Kabupaten Sidoarjo juga mendapatkan bahwa ventilasi merupakan salah satu faktor yang memengaruhi kualitas udara di lembaga pemasyarakatan. Sarana hunian yang tidak memadai ini menimbulkan keluhan seperti kulit kering, gatal, dan kulit bermiyak. ${ }^{(23)}$ Penelitian di Korea juga menyebutkan penurunan polusi udara dalam ruang dapat menurunkan prevalensi dermatitis atopik pada anak-anak. ${ }^{(24)}$ Penelitian lain juga menyebutkan adanya hubungan pencemaran udara dalam ruang dengan kejadian penyakit kulit seperti dematitis atopik. $(25,26)$

\section{Hubungan Binantang dan Vektor Pembawa Penyakit Di Rumah Dengan Keluhan Penyakit Kulit}

Berdasarkan Tabel 6 diketahui bahwa secara bivariat keberadaan binatang dan vektor pembawa penyakit di rumah tidak berhubungan signifikan terhadap kejadian keluhan penyakit kulit di masyarakat. Namun, setelah dilakukan analisis regresi logistik, didapatkan keberadaan serangga di rumah menjadi faktor risiko timbulnya keluhan penyakit kulit di masyarakat (Tabel 8).

Tabel 6 Hubungan Binatang dan Vektor Pembawa Penyakit Di Rumah dengan Keluhan Penyakit Kulit

\begin{tabular}{|c|c|c|c|c|c|c|}
\hline \multirow[t]{2}{*}{ No } & \multirow{2}{*}{$\begin{array}{l}\text { Keberadaan vektor dan binatang pembawa } \\
\text { penyakit di dalam rumah }\end{array}$} & \multicolumn{4}{|c|}{ Keluhan penyakit Kulit } & \multirow[t]{2}{*}{ p value } \\
\hline & & $\begin{array}{c}\text { Ya } \\
(\mathbf{n}=90)\end{array}$ & $\%$ & $\begin{array}{c}\text { Tidak } \\
(n=155)\end{array}$ & $\%$ & \\
\hline \multirow[t]{3}{*}{1} & Terdapat tikus/tanda keberadaan tikus & & & & & 1 \\
\hline & Ya & 61 & 37 & 104 & 63 & \\
\hline & Tidak & 29 & 36,2 & 51 & 63,8 & \\
\hline \multirow[t]{3}{*}{2} & Terdapat kecoa/tanda keberadaan kecoa & & & & & 0,74 \\
\hline & Ya & 69 & 35,9 & 123 & 64,1 & \\
\hline & Tidak & 21 & 39,6 & 32 & 60,4 & \\
\hline \multirow[t]{3}{*}{3} & Terdapat nyamuk/tanda keberadaan nyamuk & & & & & 0,453 \\
\hline & Ya & 79 & 35,7 & 142 & 64,3 & \\
\hline & Tidak & 11 & 45,1 & 13 & 54,2 & \\
\hline \multirow[t]{3}{*}{4} & $\begin{array}{l}\text { Terdapat serangga/tanda keberadaan serangga } \\
\text { (semut dan kumbang ) }\end{array}$ & & & & & 0,052 \\
\hline & $\mathrm{Ya}$ & 68 & 41,2 & 97 & 58,8 & \\
\hline & Tidak & 22 & 27,5 & 58 & 72,5 & \\
\hline \multirow[t]{3}{*}{5} & $\begin{array}{l}\text { Terdapat binatang (kucing atau reptil atau } \\
\text { burung) }\end{array}$ & & & & & 0,692 \\
\hline & $\mathrm{Ya}$ & 35 & 38,9 & 55 & 61,1 & \\
\hline & Tidak & 55 & 36,7 & 100 & 63,3 & \\
\hline
\end{tabular}

Faktor risiko lingkungan lainnya yang berhubungan dengan penyakit kulit dalam penelitian ini adalah adanya serangga/tanda keberadaan serangga (semut dan kumbang) di dalam rumah. Pada penelitian ini, adjusted OR menunjukkan kejadian keluhan penyakit kulit lebih besar 2,44 kali pada pada rumah yang terdapat serangga/tanda keberadaan serangga dibandingkan yang tidak.

Gigitan atau sengatan serangga dapat menimbulkan berbagai reaksi yang bersifat lokal, seperti ruam kulit, kemerahan, bengkak, nyeri, dan luka terbakar, maupun reaksi yang bersifat sistemik yang dapat menimbulkan efek hilangnya kesadaran yang disebut syok anafilaktik sampai terjadi kematian. ${ }^{(27)}$ Gigitan serangga ini dapat bermanifestasi sebagai lesi kulit dalam bentuk bintik-bintik atau bercak kemerahan yang disertai dengan adanya bengkak akibat trauma langsung, reaksi peradangan, ataupun reaksi alergi terhadap air liur serangga. Lesi kulit ini juga dapat berkembang menjadi lokasi infeksi sekunder oleh bakteri. Hal ini dapat menimbulkan reaksi lokal pada kulit, gigitan atau sengatan serangga, juga dapat berperan sebagai jalur transmisi virus, bakteri, atau protozoa lainnya. Reaksi sistemik gigitan 
atau sengatan dari serangga juga bervariasi, mulai dari gangguan saraf, gangguan saraf otonom, hingga kegagalan organ. ${ }^{(13)}$

Berikut ini digambarkan pemodelan hubungan faktor risiko sanitasi lingkungan dengan keluhan penyakit kulit di masyarakat melalui analysis regresi logistik ganda. Model awal dapat dilihat pada Tabel 7 di bawah ini:

Tabel 7 Model Awal Analisis Regresi Logistik Ganda

\begin{tabular}{clcc}
\hline No & \multicolumn{1}{c}{ Variabel } & p value & OR \\
\hline 1 & Sumber Air Bersih & 0,123 & 0,467 \\
2 & Sumber Air Minum & 0,014 & $0, .426$ \\
3 & Jenis (SPAL) yang digunakan di rumah & 0,025 & 2,416 \\
4 & Ventilasi < 20\% dari luas lantai & 0,000 & 6,119 \\
5 & Ventilasi kamar tidur > 20\% dari luas lantai & 0,768 & 1,110 \\
6 & Kepadatan kamar tidur mencukupi & 0,434 & 1,269 \\
7 & Terdapat serangga/tanda keberadaan serangga & 0,017 & 2,260 \\
\hline
\end{tabular}

Tabel 8 Model Akhir Analisis Regresi Logistik Ganda

\begin{tabular}{clccc}
\hline No & \multicolumn{1}{c}{ Variabel } & p value & OR & $\mathbf{9 5 \%}$ CI \\
\hline 1 & Sumber Air Bersih & 0,09 & 0,43 & $0,16-1,13$ \\
2 & Sumber Air Minum & 0,01 & 0,42 & $0,21-0,82$ \\
3 & Jenis SPAL yang digunakan di rumah & 0,02 & 2,51 & $1,15-5,44$ \\
4 & Ventilasi < 20\% dari luas lantai & 0,001 & 6,24 & $2,56-15,68$ \\
5 & Terdapat serangga/tanda keberadaan serangga & 0,007 & 2,44 & $1,2-4,66$ \\
\hline
\end{tabular}

Berdasarkan Tabel 7 di atas, dapat dilihat ventilasi kamar tidur, kepadatan kamar tidur, dan sumber air bersih tidak signifikan ( $p$ value $<0,05)$. Oleh karena itu variabel tersebut dikeluarkan satu persatu dan dihitung perubahan OR pada variabel lainnya.

Berdasarkan Tabel 8 di atas, variabel/faktor risiko yang terbukti berhubungan dengan keluhan penyakit kulit adalah jenis SPAL yang digunakan di rumah, ventilasi $<20 \%$ luas lantai, dan terdapat keberadaan serangga/tanda keberadaan serangga (semut dan kumbang). Faktor risiko yang paling berpengaruh terhadap keluhan penyakit kulit di masyarakat adalah ventilasi ruang keluarga ( $p$ value 0,0001 , adjusted OR 6,34), kemudian SPAL ( $p$ value 0,02 adjusted OR 2,51), dan keberadaan serangga di dalam rumah ( $p$ value 0,007 adjusted OR 2,44).

\section{SIMPULAN}

Hasil penelitian ini menunjukkan sebanyak 90 orang $(36,73 \%$; 95\% CI 30,69\% - 42,76\%) mengalami keluhan penyakit kulit selama 1 bulan terakhir. Secara simultan, faktor lingkungan yang berhubungan terhahap keluhan penyakit kulit di masyarakat adalah ventilasi udara yang kurang (terutama di ruang keluarga), SPAL yang tidak sehat, dan keberadaan keberadaan vektor (khususnya dari golongan serangga) pembawa penyakit di rumah. Selanjutnya, peneliti merekomendasikan kepada petugas Puskesmas, khususnya pemegang program upaya Kesehatan lingkungan dapat memperhatikan kondisi pemukiman masyarakat yang ada diwilayah kerjanya untuk memperhatikan kondisi perumahan warga, terutama dalam hal ventilasi rumah, SPAL yang sehat serta pengendalian vector, karena terbukti berhubungan dengan keluhan penyakit kulit masyarakat.

\section{UCAPAN TERIMA KASIH}

Tim peneliti mengucapkan terima kasih kepada Fakultas Kedokteran Universitas Riau dan Lembaga Penelitian dan Pengabdian kepada Masyarakat (LPPM) Universitas Riau yang telah membantu memfasilitasi dan mendanai penelitian ini.

\section{DAFTAR PUSTAKA}

1. Greaves MW. Skin disease: Encyclopedia Britannica; 2020 [Available from: https:/www.britannica.com/science/human-skindisease.

2. Tyring S. Tropical Dermatology: Elsevier Health Sciences; $2017 . \quad 376-86$ p. https://doi.org/10.1016/B978-0-323-296342.00001-8

3. Siregar RS. Penyakit Jamur Kulit: Egc.

4. Mistık S, Uludağ A, Kartal D, Çınar S. Bacterial Skin Infections: Epidemiology and Latest Research. Turkish Journal of Family Medicine \& Primary Care. 2015;9(2):65-74. https://doi.org/10.5455/tjfmpc.177379

5. WHO. Scabies and other ectoparasites 2017 [Available from: https://www.who.int/neglected_diseases/diseases/s cabies/en/.

6. Griana TP. Scabies: Penyebab, Penanganan Dan Pencegahannya. El-Hayah. 2013;4(1). https://doi.org/10.18860/elha.v4i1.2619 
7. Achmadi UF. Manajemen Penyakit Berbasis Wilayah. Jakarta: Raja Grafindo; 2012.

8. KBBI. Sanitasi [cited 202121 Februari]. Available from: https://kbbi.web.id/sanitasi.

9. WHO. Guidelines on sanitation and health. 2018:4.

10. Hamzah Z, Handayani ATW, Prihatiningrum B, Tohirun T, Indartin D, Ernanda H, et al., editors. Water Pollution in Bedadung Watersheds Area and Diseases in Elderly People. International Conference in Health Sciences (ICHS); 2017; Purwokerto. Purwokerto: Universitas Jenderal Soedirman; 2018.

11. Mosites E, Lefferts B, Seeman S, January G, Dobson J, Fuente D, et al. Community water service and incidence of respiratory, skin, and gastrointestinal infections in rural Alaska, 20132015. International Journal of Hygiene and Environmental Health. 2020;225:113475. https://doi.org/10.1016/j.ijheh.2020.113475

12. Sajida A, Santi DN, Naria E. Hubungan personal hygiene dan sanitasi lingkungan dengan keluhan penyakit kulit di Kelurahan Denai Kecamatan Medan denai Kota Medan Tahun 2012. Lingkungan dan Kesehatan Kerja. 2013;2(2).

13. Kusumasari R. Gigitan atau sengatan Serangga Yogyakarta: Universitas Gadjah Mada; 2019 [Available from: https://parasito.fkkmk.ugm.ac.id/gigitan-atausengatan-serangga/.

14. Zahtamal, Restuastuti T, Restila R, Yusdiana Y, editors. Pengelolaan kesehatan kulit masyarakat pada masa pandemi Covid-19 di Desa Ranah Kecamatan Kampar. Unri Conference Series: Community Engagement; 2020.

15. Zulinda A, Yolazenia Y, Zahtamal Z. FaktorFaktor yang Memengaruhi Kejadian Pedikulosis Kapitis pada Murid Kelas III, IV, V Dan VI SDN 019 Tebing Tinggi Okura Kecamatan Rumbai Pesisir Pekanbaru. Jurnal Ilmu Kedokteran. 2017;4(1):65-9.

https://doi.org/10.26891/JIK.v4i1.2010.65-69

16. Sulistyani N, Khikmah N. The Relationship Among Pediculosis Capitis, Anemia And Learning Achievement In Elementary Students. Jurnal Penelitian Saintek. 2019;24(2):65-74. https://doi.org/10.21831/jps.v24i2.26500

17. Kementerian Kesehatan Republik Indonesia. Peraturan Menteri Kesehatan Republik Indonesia Nomor 32 Tahun 2017 Tentang Standar Baku Mutu Kesehatan Lingkungan Dan Persyaratan
Kesehatan Air Untuk Keperluan Higiene Sanitasi, Kolam Renang, Solus Per Aqua, Dan Pemandian Umum 2017.

18. Argos M, Kalra T, Pierce BL, Chen Y, Parvez F, Islam T, et al. A Prospective Study of Arsenic Exposure From Drinking Water and Incidence of Skin Lesions in Bangladesh. American Journal of Epidemiology. https://doi.org/10.1093/aje/kwr062

19. Shankar S, Shanker U, Shikha. Arsenic Contamination of Groundwater: A Review of Sources, Prevalence, Health Risks, and Strategies for Mitigation. The Scientific World Journal. 2014;2014. https://doi.org/10.1155/2014/304524

20. WHO. Guidelines for drinking-water quality. WHO chronicle. 2011;38(4):104-8.

21. Dewi AP. Hubungan personal hygiene dan sanitasi lingkungan dengan kejadian skabies di pondok pesantren al-kautsar Pekanbaru: Riau University; 2015.

22. Vidyautami DN, Huboyo HS, Hadiwidodo M. Pengaruh Penggunaan Ventilasi (AC Dan Non AC) dalam Ruangan Terhadap Keberadaan Mikroorganisme Udara (Studi Kasus: Ruang Kuliah Jurusan Teknik Sipil Universitas Diponegoro): Diponegoro University; 2015.

23. Candrasari CR, Mukono J. Hubungan Kualitas Udara dalam Ruang dengan Keluhan Penghuni Lembaga Pemasyarakatan Kelas IIA Kabupaten Sidoarjo. Jurnal Kesehatan Lingkungan. 2013;7(1):21-5.

24. Kim HO, Kim JH, Cho SI, Chung BY, Ahn IS, Lee $\mathrm{CH}$, et al. Improvement of atopic dermatitis severity after reducing indoor air pollutants. Annals of Dermatology. 2013;25(3):292-7. https://doi.org/10.5021/ad.2013.25.3.292

25. Kim E-H, Kim S, Lee JH, Kim J, Han Y, Kim Y$\mathrm{M}$, et al. Indoor air pollution aggravates symptoms of atopic dermatitis in children. PLoS One. 2015;10(3):e0119501. https://doi.org/10.1371/journal.pone.0119501

26. Ahn K. The role of air pollutants in atopic dermatitis. Journal of Allergy and Clinical Immunology. 2014;134(5):993-9. https://doi.org/10.1016/j.jaci.2014.09.023

27. Pertiwi AM, Saimora AF, Cahyani SL, Prabhawati TB, Andarini DW, Sari EP, et al. Identifikasi Penanganan Sengatan Dan Gigitan Serangga Di Masyarakat. Jurnal Farmasi Komunitas. 2018; Vol 5 No 2:50 - 5. 